\title{
MIR148A Gene
}

National Cancer Institute

\section{Source}

National Cancer Institute. MIR148A Gene. NCI Thesaurus. Code C81742.

This gene is involved in the regulation of gene expression. While it has no known role in oncogenesis, MIR148A plays a role in the development of asthma. 